\title{
SUBSTRATE EFFECTS ON THE ENHANCED BIOTRANSFORMATION OF POLYCHLORINATED HYDROCARBONS UNDER ANAEROBIC CONDITION
}

\author{
Ruey-an Doong ${ }^{1^{*}}$ and Shian-chee $\mathrm{Wu}^{2}$ \\ 1: Institute of Nuclear Science, National Tsing Hua University, Hsinchu, 30043, Taiwan, R.O.C. \\ 2:Graduate Institute of Environmental Engineering, National Taiwan University, Taipei, 10770 \\ Taiwan, R.O.C.
}

(Received in Germany 22 November 1994; accepted 23 December 1994)

\begin{abstract}
An investigation involving the effects of different substrates on the biotransformation of heavily chlorinated hydrocarbons was performed under anaerobic condition to assess the availability of the substrate on the in situ bioremediation of contaminated groundwaters. The substrate-fed batches were anaerobically incubated with either acetate, glucose, methanol, or humic acid (HA) as supplemental substrate with concentrations ranging from 10 to $30 \mathrm{mg} / \mathrm{L}$. Experimental results indicated that the rates and extents of the disappearance of the chlorinated compounds differed depending on type and concentration of the supplemental carbon sources employed. Better removal efficiencies were observed for glucose-, methanol-, and acetate-fed batches, and least for HA-fed batches. The sequence of the efficiency of enhancement is consistent with the sequence of the reducing potentials of the dechlorination reactions. When the substrate concentrations in the batches were increased from 10 to $30 \mathrm{mg} / \mathrm{L}$, highest removal efficiencies of carbon tetrachloride (CT), tetrachloroethylene (PCE), and 1,1,1-trichloroethane (TCA) increased from $96 \%, 49 \%$, and $61 \%$ to $99.9 \%, 61 \%$, and $69 \%$, respectively. The viable counts of microorganisms determined by the direct epifluorescence counting technique revealed that the batches with higher concentrations of the supplemental substrate produced higher bacterial cell numbers. Moreover, from microscopic observations, different compositions of bacterial population were found. Small bacteria with spheric shape were observed when culture bottles were amended with either acetate or HA. Whereas, large bacteria with rod-shape were predominant in bottles amended with glucose. Also, higher DNA contents were demonstrated for glucose-fed batches.
\end{abstract}




\section{INTRODUCTION}

Volatile chlorinated aliphatic hydrocarbons are among the most often found contaminants in soils and groundwaters (1). These compounds are used in industrial and household applications for degreasing and are widely distributed in the environment due to the improper discharges of industrial and municipal wastewater, runoff from urban and agricultural area, leachates from landfills and leaking underground tanks and pipes. For their various types and degree of adverse health effects, an extensive understanding of their fates in the environment is necessary to estimate the risk of human health as well as success fully apply remedial techniques.

Biotransformation is one of the most important processes significantly influencing the fate of chlorinated hydrocarbons in natural environments. Anaerobic biotransformation of polychlorinated hydrocarbons, such as carbon tetrachloride (CT), tetrachloroethylene (PCE) and 1,1,1-trichloroethane (TCA), is of particular interest in the remediation of contaminated groundwaters because of their recalcitrance to aerobic microbial activities $(2,3)$. Heavily chlorinated hydrocarbons can be fortuitously biotransformed into less-chlorinated homologs through reductive dechlorination by heterotrophic enrichments or pure cultures under various redox conditions (4-7). Dechlorination rates are generally faster under reducing environments.

In-situ bioremediation is one of the technologies employed for the remediation of groundwaters contaminated with heavily chlorinated hydrocarbons. This process involves stimulating the activity of the microflora through the addition of carbon and energy sources (supplemental substrate) in place. However, the environmental conditions required to initiate and sustain dechlorination activity in contaminated aquifers remain unclear. Previous studies have demonstrated the effects of high concentration of supplemental substrates $(50-1000 \mathrm{mg} / \mathrm{L})$ on the biotransformation of chlorinated hydrocarbons and showed that the type of substrate could be a crucial factor influencing the biotransformation of chlorinated hydrocarbons under anaerobic conditions(8-10). Nevertheless, the situations under low substrate concentration were not considered. Also, no general rule has been proposed for selecting the appropriate supplemental substrate among many candidates. In this study, different types and low concentrations of substrates $(10-30 \mathrm{mg} / \mathrm{L})$ are provided for microbial communities to assess the substrate effect on the biotransformation of heavily chlorinated hydrocarbons. Thermodynamic explanations of the experimental results are also made on the basis of the different reducing potentials of the added substrates.

\section{MATERIALS AND METHODS}

Reagents and materials. The chlorinated hydrocarbons used in this study, carbon tetrachloride (CT) (99.8\%, GC grade); 1,1,1-trichloroethane (TCA) (99.8\%, GC grade); tetrachloroethylene (PCE) (99.8\%, GC grade); and chloroform (CF) (99.8\%, GC grad), were purchased from Merck Co., Darmstadt, Germany. Trichloroethylene (TCE) $(99.8 \%$, GC grade) was obtained from Ishizu 
Pharmaceutical Co., Osaka, Japan. The fluorescing stain, 4',6-diamidino-2-phenylindole (DAPI), and humic acid (sodium salt) were purchased from Aldrich Chemical Co., Inc., Milwaukee, Wisco., U. S. A.

Anaerobic mix-culture consortia was obtained from the anaerobic digester of the Taiwan Sugar Co. wastewater treatment facility (Hsinchu, Taiwan). It was then incubated at $35^{\circ} \mathrm{C}$ in a 2-liter glass flask with a magnetic stirrer under anaerobic condition. $200 \mathrm{ml}$ of the substrate solution consisting of acetic acid $(15000 \mathrm{mg} / \mathrm{L})$, propionic acid $(5000 \mathrm{mg} / \mathrm{L})$, vitamins, reducing agents $\left(\mathrm{Na}_{2} \mathrm{~S} ; \mathrm{FeCl}_{2}\right)$, and mineral growth factors were added into the inoculum culture daily to maintain adequate microbial activity. The supplement of auxiliary substrate solution was curtailed 2 to 3 days before the beginning of each experiment in order to exhaust the residual carbon sources in the anaerobic culture.

Biotransformation studies. $45 \mathrm{~mL}$ of the reducing media containing (per liter of deionized water) 1800 $\mathrm{mg} / \mathrm{L}$ of $\mathrm{MgCl}_{2} \cdot 6 \mathrm{H}_{2} \mathrm{O}, 1300 \mathrm{mg} / \mathrm{L}$ of $\mathrm{KCl}, 500 \mathrm{mg} / \mathrm{L}$ of $\left(\mathrm{NH}_{4}\right)_{2} \mathrm{HPO}_{4}, 250 \mathrm{mg} / \mathrm{L}$ of $\mathrm{CaCl}_{2} \cdot 2 \mathrm{H}_{2} \mathrm{O}, 400$ $\mathrm{mg} / \mathrm{L}$ of $\mathrm{NH}_{4} \mathrm{Cl}, 500 \mathrm{mg} / \mathrm{L}$ of $\mathrm{Na}_{2} \mathrm{~S} \cdot 9 \mathrm{H}_{2} \mathrm{O}, 370 \mathrm{mg} / \mathrm{L}$ of $\mathrm{FeCl}_{2} \cdot 4 \mathrm{H}_{2} \mathrm{O}, 15 \mathrm{ml}$ of a trace element solution and $1 \mathrm{ml}$ of vitamin solution $(11,12)$, were added in sterilized $60 \mathrm{ml}$ serum bottles. Serum bottles were flushed with nitrogen gas and $1 \mathrm{ml}$ aliquot of the diluted seeding culture was introduced into each serum bottle. Bottles were then sealed with Teflon-lined rubber septa and aluminum crimp caps (Wheaton Co., N. J., U.S.A.) immediately after the aqueous solutions of chlorinated hydrocarbons; in addition, the selected supplement substrates were added. The total volume of the liquid phase was $50 \mathrm{~mL} .10 \mathrm{~mL}$ headspace was left for headspace analysis.

Media containing chlorinated hydrocarbons were prepared by diluting the stock solution $(250 \mathrm{mg} / \mathrm{mL}$ in methanol) to give the concentration of $100 \mu \mathrm{g} / \mathrm{L}$. Aqueous forms of the organic substrates were introduced into the serum bottles to give concentrations of 10 to $30 \mathrm{mg} / \mathrm{L}$ (to $250 \mathrm{mg} / \mathrm{L}$ for methanol). The influence of organic substrates on the anaerobic dechlorination of chlorinated hydrocarbons was investigated by adding acetate, glucose, methanol, and humic acid (a natural dissolved organic matter) in the media. Acetate and glucose were added as the supplemental substrates for testing the availability on the enhanced dechlorination. Humic acid (HA) was used to simulate the natural carbon source in groundwater. Methanol was also tested because of its common application as a solvent for chlorinated hydrocarbons in laboratory studies.

Blank controls were performed by following the procedures described above, but $10 \mathrm{mg} / \mathrm{L} \mathrm{of} \mathrm{HgCl}_{2}$ was added as microbial growth inhibitor. The variable counts revealed that the microbial activities in the solutions in blank controls were less than $10^{2}$ cells $/ \mathrm{mL}$ over the experimental period and can be neglected by the comparison of the seeded microcosms $\left(10^{5} \mathrm{cells} / \mathrm{mL}\right)$. All serum bottles were wrapped with aluminum foil to avoid photodecomposition and incubated in dark at $35^{\circ} \mathrm{C}$.

Analytical Methods. The concentrations of chlorinated compounds in the headspace of the test bottles were monitored by drawing $5 \mu \mathrm{L}$ of the gas phase and $10 \mu \mathrm{L}$ gas in the headspace of the internal standard (bromoform) with a $25 \mu \mathrm{L}$ gas-tight syringe (Hamilton, cat. No. 1702N) and injecting the mixture into a gas chromatograph (model 5890A, Hewlett-Packard, Avondale, Pa., U.S.A.) equipped 
with a ${ }^{63} \mathrm{Ni}$ coated electron capture detector (ECD). A DB-624 fused-silica megabore capillary column ( $30 \mathrm{~m} \times 0.545 \mathrm{~mm} \times 3.0 \mu \mathrm{m}, \mathrm{J} \& \mathrm{~W}$ Scientific Inc., Folsom, CA.) was used for the separation of the chlorinated compounds. The column temperature was maintained at $35^{\circ} \mathrm{C}$ for 1 minute, then programmed to $50^{\circ} \mathrm{C}$ at a rate of $2^{\circ} \mathrm{C} / \mathrm{min}$. and heated to $150^{\circ} \mathrm{C}$ at rate of $8^{\circ} \mathrm{C} / \mathrm{min}$. with carrier gas $\left(\mathrm{N}_{2}\right)$ flow rate of $5.6 \mathrm{~mL} / \mathrm{min}$. (linear velocity $42.3 \mathrm{~cm} / \mathrm{sec}$ ). Injector and detector temperatures were $200^{\circ} \mathrm{C}$ and $300^{\circ} \mathrm{C}$, respectively. The analytical error was controlled within $5 \%$. The error was determined by calculating the relative standard deviation (RSD) of the peak area of the internal standard $(n=20-26)$ and frequently checked with a standard solution and samples triply during the analysis. The detection limits, in terms of the concentrations in aqueous solutions, were $0.21 \mu \mathrm{g} / \mathrm{L}$ for TCA, $0.10 \mu \mathrm{g} / \mathrm{L}$ for CT, $0.60 \mu \mathrm{g} / \mathrm{L}$ for $\mathrm{CF}$, and $0.24 \mu \mathrm{g} / \mathrm{L}$ for PCE.

The test bottles were opened after headspace analyses, and $\mathrm{pH}$, the oxidation-reduction potential (ORP), TOC, and the microbial activities in the liquid phases were analyzed. ORP and $\mathrm{pH}$ were determined via an Orion EA 920 expandable ion analyzer (Orion Research Inc., Boston., MA.) by using an Orion gel-filled combination $\mathrm{pH}$ electrode for $\mathrm{pH}$ measurements and an Orion model 97-78-00 Pt redox electrode for ORP measurements. For ORP measurements the electrode was calibrated with ferrous-ferric solution (13). During the experimental course, values in the range of -420 to $137 \mathrm{mV}$ were measured, which is considered as an anaerobic condition (14). Total organic carbon (TOC) was analyzed with a model 700 TOC analyzer (O. I. Corporation, College Station, Texas, U.S.A.) by using wet-oxidation method with sodium persulfate $\left(\mathrm{Na}_{2} \mathrm{~S}_{2} \mathrm{O}_{8}\right)$ as oxidant

The microbial activities in the solutions in test bottles were determined by viable count with an epifluorescence technique, the DAPI method (15). An epifluorescence microscope equipped with a Nikon mercury lamp supply HB0-100W/2 (Dichroic mirror: $400 \mathrm{~nm}$; Excitation filter: $330 \sim 380 \mathrm{~nm}$, Barrier filter: $435 \mathrm{~nm}$, Nikon, Tokyo, Japan) was used to count the numbers of viable cells of each sample. $10 \mathrm{~mL}$ of sample was fixed with $0.5 \mathrm{~mL}$ of filtered Formalin ( $37 \%$ formaldehyde) and was stained with $1 \mathrm{~mL}$ of DAPI solution at the concentration of $0.1 \mathrm{mg} / \mathrm{mL}$ (with the final concentration of $0.01 \mathrm{mg} / \mathrm{mL}$ ). Samples were then filtered through $0.2 \mathrm{~mm}$ cellulose nitrate filters $(25 \mathrm{~mm}$, Sartorius, Goettingen, Germany) and mounted in glycerol. Samples were stored in $4^{\circ} \mathrm{C}$ before the microscopic observations.

\section{RESULTS AND DISCUSSION}

Effect of organic substrates. The biotransformations of chlorinated hydrocarbons with the addition of different organic substrates at concentration of $30 \mathrm{mg} / \mathrm{L}$ are illustrated in Figure 1 to Figure 3. Similar patterns of transformation of chlorinated hydrocarbons were observed among batches that were fed with different substrates. However, the extent of dechlorination differed depending upon the substrate employed. Better removal efficiency was found for glucose-, methanol-, and acetate-fed batches in sequence and least for HA-fed batch. A comparison of substrate-fed batches with blank controls revealed that the dechlorination of the chlorinated hydrocarbons was mediated by microbial consortia. 
The decrease of CT concentration of blank control is due to the abiotic reaction, as well documented by many investigations (16-18).

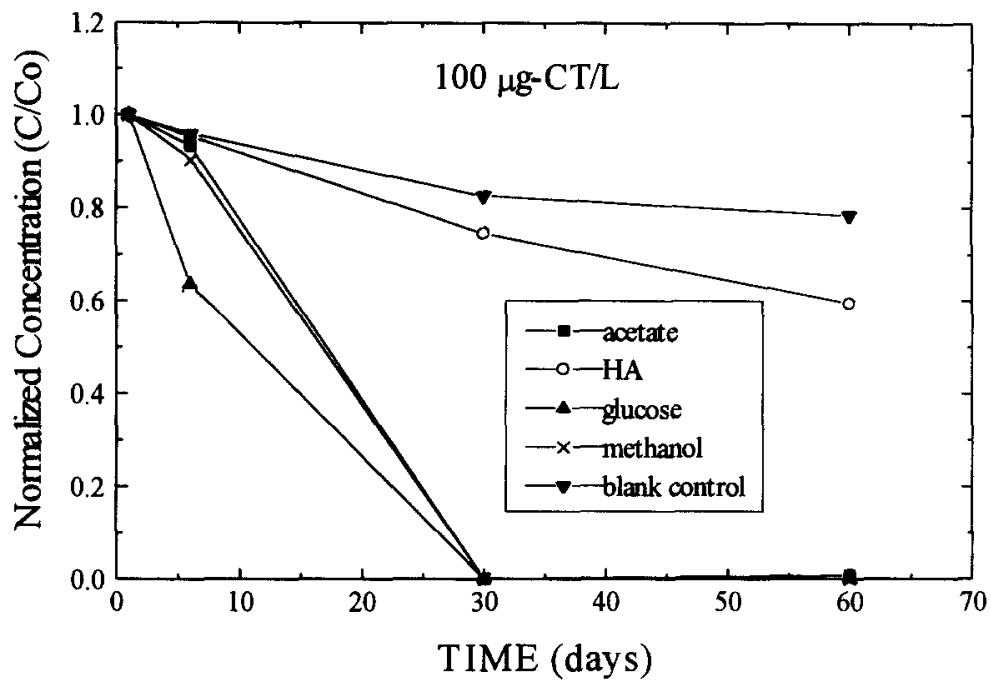

Figure 1. The biotransformation of $\mathrm{CT}$ with the addition of different organic substrates at concentration of $30 \mathrm{mg} / \mathrm{L}$. The supplemental substrates applied into the batches were glucose, acetate, methanol, and humic acid (HA), respectively.

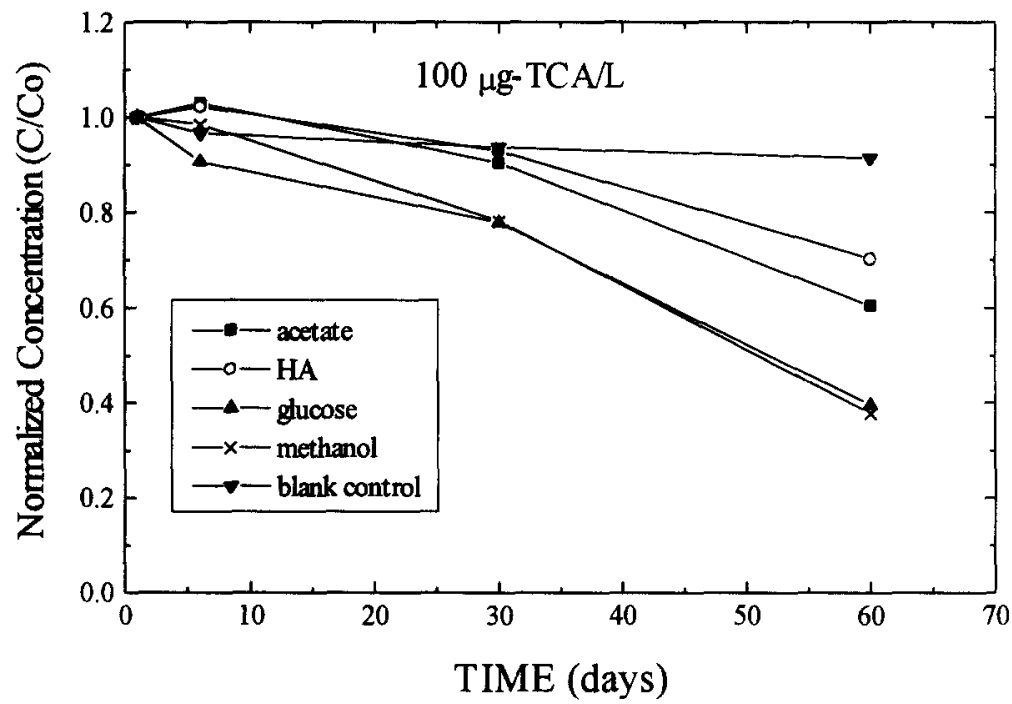

Figure 2. The biotransformation of TCA with the addition of different organic substrates at concentration of $30 \mathrm{mg} / \mathrm{L}$. The supplemental substrates applied into the batches were glucose, acetate, methanol, and humic acid (HA), respectively. 
According to thermodynamic rule, the readiness of the dechlorination reaction should be correlated with the change of the free energy of the reaction. In a contaminated system, added substrates provide reducing potential (electron activity) to drive dechlorination of chlorinated hydrocarbons. Table 1 summarizes the reactions of dechlorination of polychlorinated hydrocarbons by the addition of supplemental substrates and the standard free energies of the reactions. This addition is made under the assumption that the carbon source (electron donor) is completely converted to carbon dioxide $\left(\mathrm{CO}_{2}\right)$ and methane $\left(\mathrm{CH}_{4}\right)(10,19)$. From Table 1, We can infer that glucose and methanol are the better supplemental substrates to initiate the dechlorination reaction due to their more negative standard energies and that acetate is less favorable as a supplemental reducer. Also, CT may be more susceptible to the dechlorination reaction for its more negative standard free energy and the rate of biotransformation of TCA is lower for its less negative standard free energy

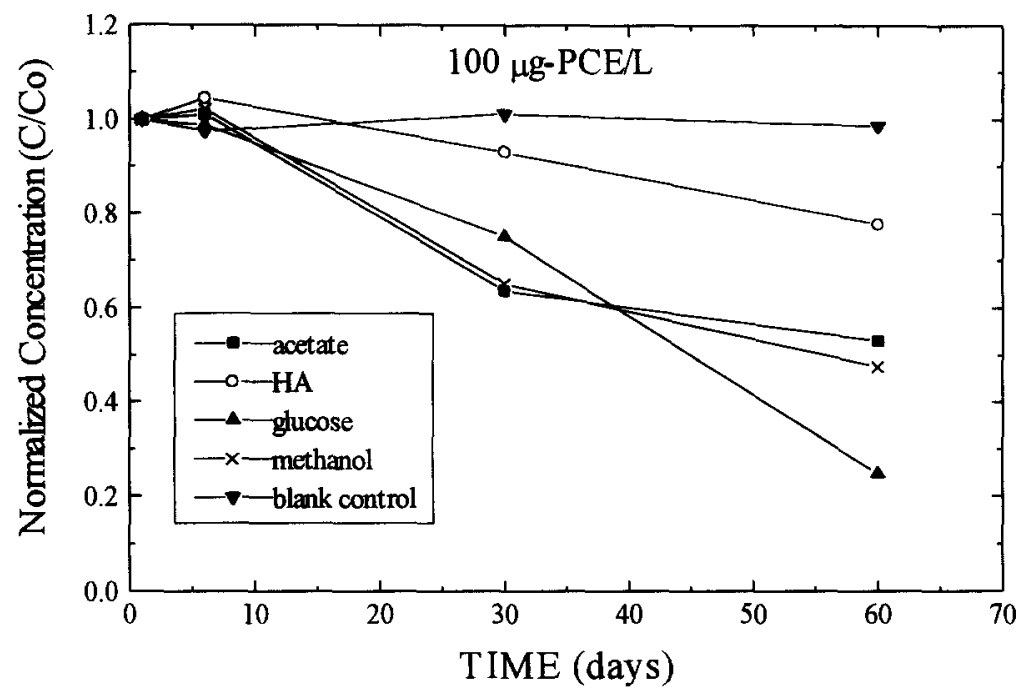

Figure 3. The biotransformation of PCE with the addition of different organic substrates at concentration of $30 \mathrm{mg} / \mathrm{L}$. The supplemental substrates applied into the batches were glucose, acetate, methanol, and humic acid (HA), respectively.

Field and laboratory results demonstrate that the addition of supplemental carbon and energy sources (electron donor) is necessary for microorganisms during the onset of the degradation of trace-level organic compounds $(4,8,10,20-22)$. Nies and Vogel (20) demonstrated that the relative rates and extents of dechlorination of PCBs (Arcolor 1254) varied and were greatest for methanol-, glucose-, and acetone-fed batches and least for acetate-fed batches. Freedman and Gossett (8) also depicted that methanol was the most effective auxiliary substrate, even though glucose, hydrogen, formate, and acetate can also served as the carbon and energy sources. However, Fathepure and Vogel (22) concluded that acetate was a more most effective carbon source than glucose and methanol when a 
two-stage anaerobic-aerobic biofilm reactor was used to degrade chlorinated hydrocarbons. Exactly why methanol is often the most effective source of reducing power remains unclear. DiStefano et al. (10) showed that hydrogen was the direct electron donor used for dechlorination , thereby suggesting that methanol merely functioned as precursors for formation of an intermediate hydrogen pool. It can postulate that some intermediate electron donors such as hydrogen may be produced during the metabolic process of methanol, subsequently facilitating the dechlorination process more readily.

Table 1. Standard free energy of reductive dechlorination of chlorinated hydrocarbons (electron acceptor) with various auxiliary substrates (electron donor)

\begin{tabular}{clc}
\hline $\begin{array}{c}\text { Auxiliary } \\
\text { substrate }\end{array}$ & \multicolumn{1}{c}{ Reaction } & $\begin{array}{c}\text { Free energy }\left(\triangle \mathrm{G}_{\mathrm{f}}^{\circ}\right) \\
(\mathrm{Kcal} / \mathrm{mole})\end{array}$ \\
\hline Glucose & $\mathrm{C}_{6} \mathrm{H}_{12} \mathrm{O}_{6}+\mathrm{CCl}_{4}+\mathrm{H}_{2}=3 \mathrm{CH}_{4}+3 \mathrm{CO}_{2}+\mathrm{CHCl}_{3}+\mathrm{H}^{+}+\mathrm{Cl}^{-}$ & -138.48 \\
& $\mathrm{C}_{6} \mathrm{H}_{12} \mathrm{O}_{6}+\mathrm{CCl}_{2} \mathrm{CCl}_{2}+\mathrm{H}_{2}=3 \mathrm{CH}_{4}+3 \mathrm{CO}_{2}+\mathrm{CHClCCl}_{2}+\mathrm{H}^{+}+\mathrm{Cl}^{-}$ & -133.78 \\
& $\mathrm{C}_{6} \mathrm{H}_{12} \mathrm{O}_{6}+\mathrm{CH}_{3} \mathrm{CCl}_{3}+\mathrm{H}_{2}=3 \mathrm{CH}_{4}+3 \mathrm{CO}_{2}+\mathrm{CH}_{2} \mathrm{CHCl}_{2}+\mathrm{H}^{+}+\mathrm{Cl}^{-}$ & -133.24 \\
Methanol & $\mathrm{CH}_{3} \mathrm{OH}+\mathrm{CCl}_{4}+2 \mathrm{H}_{2}=\mathrm{CH}_{4}+\mathrm{H}_{2} \mathrm{O}+\mathrm{CHCl}_{3}+\mathrm{H}^{+}+\mathrm{Cl}^{-}$ & -65.64 \\
& $\mathrm{CH}_{3} \mathrm{OH}+\mathrm{CCl}_{2} \mathrm{CCl}_{2}+2 \mathrm{H}_{2}=\mathrm{CH}_{4}+\mathrm{H}_{2} \mathrm{O}+\mathrm{CHClCCl}_{2}+\mathrm{H}^{+}+\mathrm{Cl}^{-}$ & -60.94 \\
& $\mathrm{CH}_{3} \mathrm{OH}+\mathrm{CH}_{3} \mathrm{CCl}_{3}+2 \mathrm{H}_{2}=\mathrm{CH}_{4}+\mathrm{H}_{2} \mathrm{O}+\mathrm{CH}_{2} \mathrm{CHCl}_{2}+\mathrm{H}^{+}+\mathrm{Cl}^{-}$ & -60.40 \\
Acetate & $\mathrm{CH}_{3} \mathrm{COOH}+\mathrm{CCl}_{4}+\mathrm{H}_{2}=\mathrm{CH}_{4}+\mathrm{CO}_{2}+\mathrm{CHCl}_{3}+\mathrm{H}^{+}+\mathrm{Cl}^{-}$ & -53.05 \\
& $\mathrm{CH}_{3} \mathrm{COOH}+\mathrm{CCl}_{2} \mathrm{CCl}_{2}+\mathrm{H}_{2}=\mathrm{CH}_{4}+\mathrm{CO}_{2}+\mathrm{CHClCl}_{2}+\mathrm{H}^{+}+\mathrm{Cl}^{-}$ & -48.35 \\
& $\mathrm{CH}_{3} \mathrm{COOH}+\mathrm{CH}_{3} \mathrm{CCl}_{3}+\mathrm{H}_{2}=\mathrm{CH}_{4}+\mathrm{CO}_{2}+\mathrm{CH}_{2} \mathrm{CHCl}_{2}+\mathrm{H}^{+}+\mathrm{Cl}^{-}$ & -47.81
\end{tabular}

Effect of the substrate concentrations. The concentration effect of the organic substrates on the transformation of the chlorinated hydrocarbons is summarized in Table 2. An increase of organic substrate concentration would result in the increase of the removal ratio of the chlorinated hydrocarbons. As shown in Table 2, removal fractions ranging from $40 \%$ to $99.6 \%, 19 \%$ to $51 \%$ and $14 \%$ to $50 \%$ of the original concentrations of CT, TCA and PCE, respectively, were observed in 60 days when microcosms were amended with carbon source at the concentration of $10 \mathrm{mg} / \mathrm{L}$. As the substrate concentration increased to $30 \mathrm{mg} / \mathrm{L}$, the culture bottles exhibited better removal and extended from $41 \%$ to $99.9 \%, 30 \%$ to $63 \%$, and $20 \%$ to $75 \%$ of the original CT, TCA, and PCE, respectively, added in 60 days. These findings implies that substrate concentration can affect the dechlorination capability of microbial communities. 
Table 2. Removal ratios of the chlorinated hydrocarbons with different organic substrates in 60 days. The concentrations of the supplemental substrate were 10,20 , and $30 \mathrm{mg} / \mathrm{L}$, respectively.

\section{Removal ratio (1- C/Co.)}

\begin{tabular}{|c|c|c|c|c|c|c|c|c|c|c|c|c|}
\hline \multirow{2}{*}{ Pollutant } & \multicolumn{3}{|c|}{ Acetate-fed } & \multicolumn{3}{|c|}{ HA-fed } & \multicolumn{3}{|c|}{ Glucose-fed } & \multicolumn{3}{|c|}{ Methanol-fed } \\
\hline & 10 & $\begin{array}{c}20 \\
(\mathrm{mg} / \mathrm{L})\end{array}$ & 30 & 10 & $\begin{array}{c}20 \\
(\mathrm{mg} / \mathrm{L})\end{array}$ & 30 & 10 & $\begin{array}{c}20 \\
(\mathrm{mg} / \mathrm{L})\end{array}$ & 30 & 10 & $\begin{array}{c}20 \\
(\mathrm{mg} / \mathrm{L})\end{array}$ & 30 \\
\hline CT & 0.551 & 0.999 & 0.992 & 0.400 & - & 0.405 & 0.996 & 0.995 & 0.999 & 0.77 & 0.999 & 0.999 \\
\hline PCE & 0.501 & 0.469 & 0.511 & 0.135 & 0.184 & 0.202 & 0.669 & 0.652 & 0.752 & 0.513 & 0.539 & 0.524 \\
\hline TCA & 0.329 & 0.339 & 0.394 & 0.187 & 0.240 & 0.296 & 0.508 & 0.575 & 0.603 & 0.437 & 0.504 & 0.631 \\
\hline
\end{tabular}

_: no data determined.

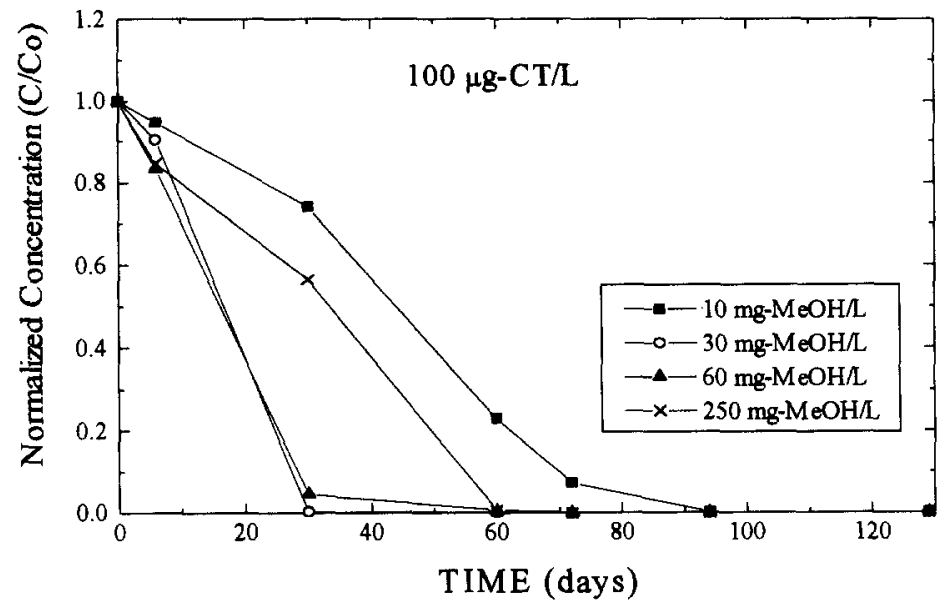

Figure 4. The biotransformation of CT in the methanol-fed batches with the amendment of different concentrations of methanol ranging from 10 to $250 \mathrm{mg} / \mathrm{L}$.

The substrate concentration effect on the biotransformation of chlorinated hydrocarbons was further clarified by supplementing higher concentrations of methanol $(60 \mathrm{mg} / \mathrm{L}$ and $250 \mathrm{mg} / \mathrm{L})$ into the microcosms. Figure 4 to Figure 6 illustrate the biotransformations of CT, PCE, and TCA, respectively, with the amendment of different concentrations of methanol ranging from 10 to $250 \mathrm{mg} / \mathrm{L}$. As depicted in Figure 4, CT degradation rate increased with an increase in the substrate concentration. $99.9 \%$ removal of the original concentration of CT was observed after 30 to 129 days when the bottle received different concentrations of methanol ranging from 10 to $250 \mathrm{mg} / \mathrm{L}$. Similarly, removal of 70 to $88 \%$ and $55 \%$ to $88 \%$ of the original PCE and TCA, respectively, was demonstrated within 129 days (Figures 5 and 6). This result is consistent with the prediction based on the thermodynamic 
calculation. Also, no significant difference of removal efficiency was observed for CT and PCE, revealing that suitable electron donor is effective in dechlorination of the compounds at appreciable rates even at a lower concentration under anaerobic condition. The supplement of low concentration of auxiliary substrate is a feasible alternative for the bioremediation of groundwaters contaminated with PCE and CT. However, enhancement of dechlorination by further higher concentration of supplemental substrate was indicated when groundwaters was contaminated with TCA.

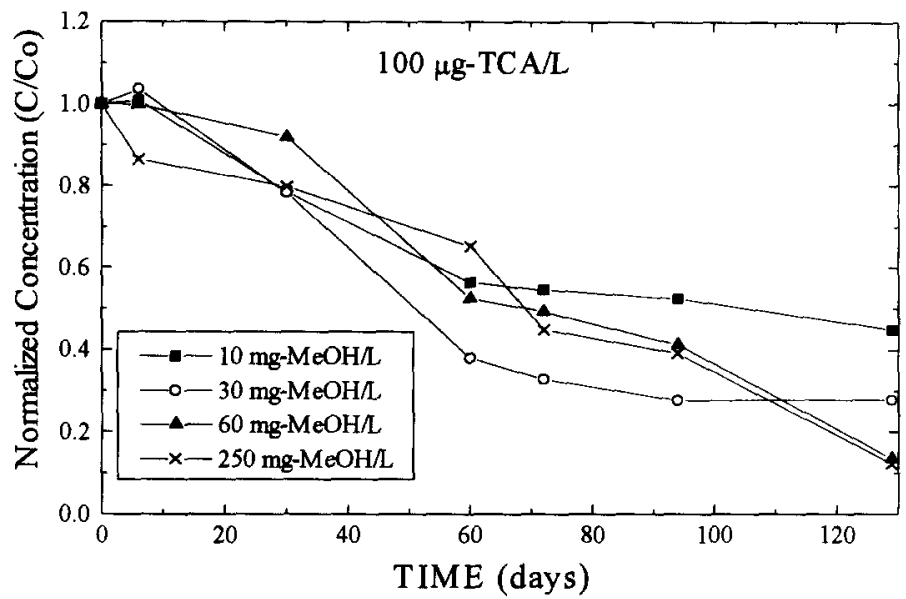

Figure 5. The biotransformation of TCA in the methanol-fed batches with the amendment of different concentrations of methanol ranging from 10 to $250 \mathrm{mg} / \mathrm{L}$.

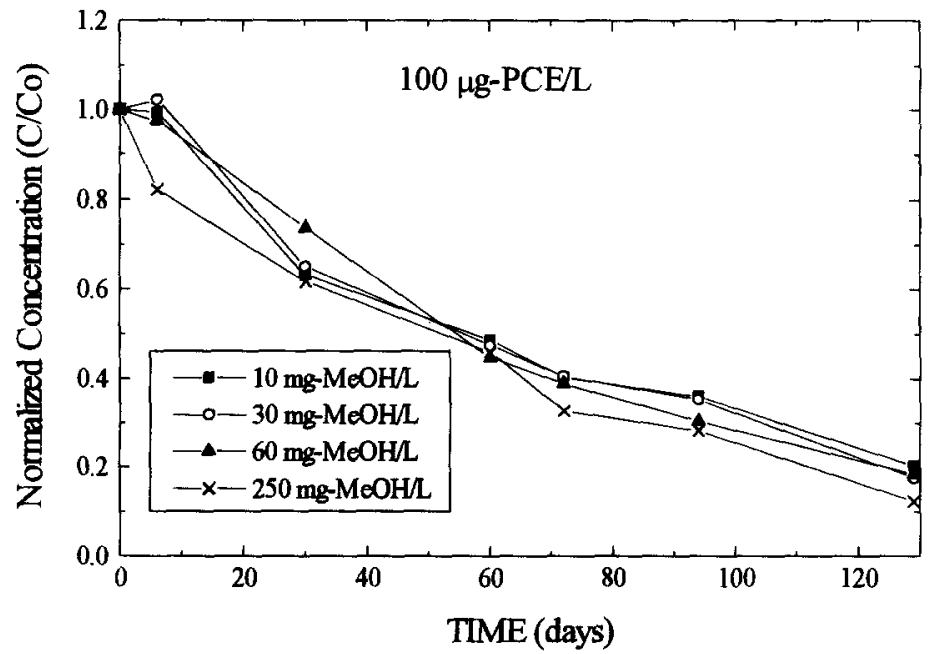

Figure 6. The biotransformation of PCE in the methanol-fed batches with the amendment of different concentrations of methanol ranging from 10 to $250 \mathrm{mg} / \mathrm{L}$. 
The microbial activities and TOC concentration. The viable count of microorganisms in the liquid phase of microcosms determined by the direct epifluorescence counting technique is shown in Figure 7 Batches with a higher concentration of organic substrate produced higher bacterial cell numbers. A 2to 4-folds increase of bacterial numbers relative to the initial cell numbers were observed in 30 days when bottles were amended with $10 \mathrm{mg} / \mathrm{L}$ of supplemental substrate. Meanwhile, a 3- to 5-folds increase was observed when $30 \mathrm{mg} / \mathrm{L}$ organic substrate were supplemented into the microcosms. The cell numbers on day 60 indicated that microbial activities were decreased. Kastner (23) also depicted that the number of cells in dechlorinating cultures was decreasing and suggested that dying cells are involved in dechlorination as well. In this study, the TOC concentrations in the liquid phases decreased within 30 days, revealing that supplemental substrates function as the carbon and energy sources for microbial communities. Interestingly, TOC concentrations on the day 60 slightly increased, depicting that dying cells released organic compounds into the environment.
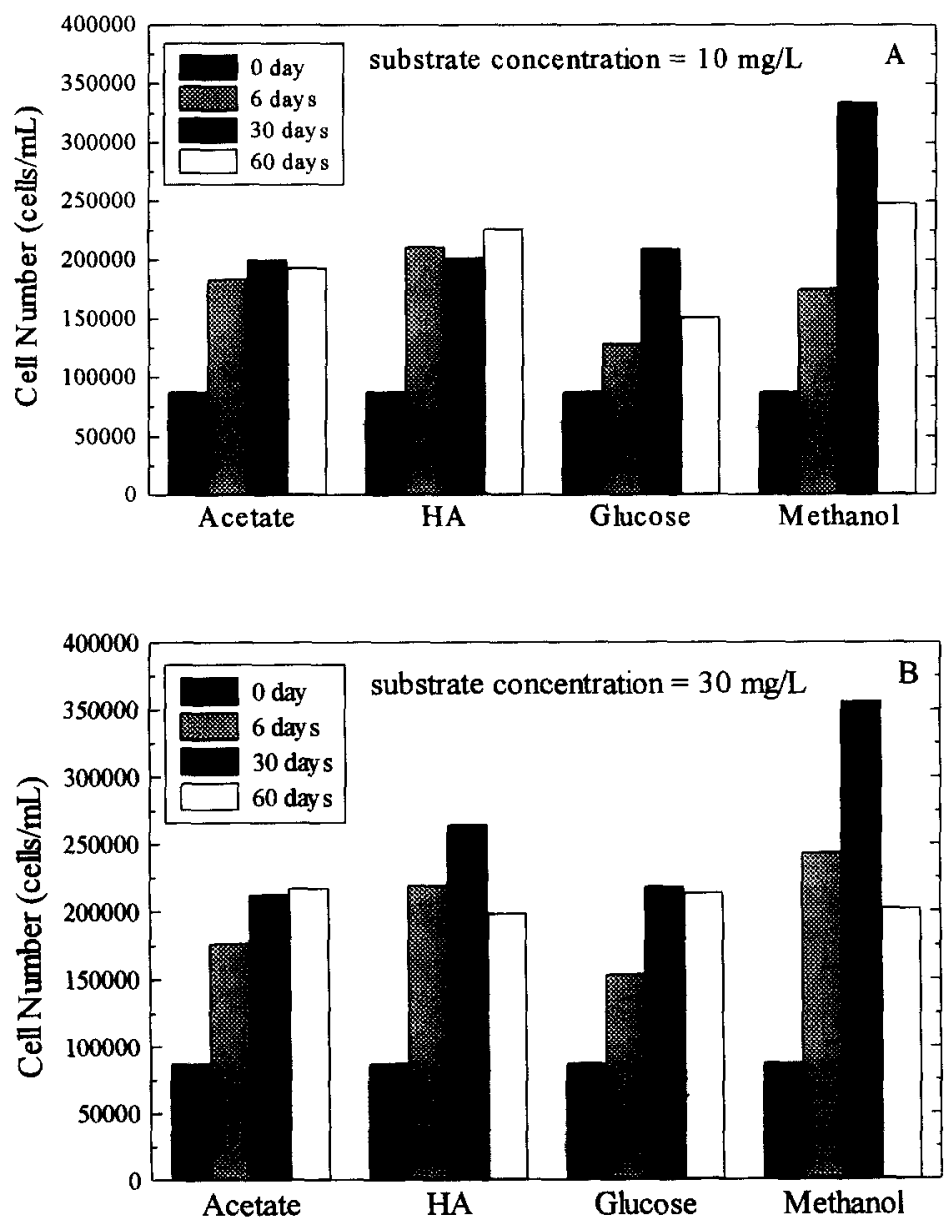

Figure 7. The viable number of cells in the liquid phases of the batches with the amendment of 10 or $30 \mathrm{mg} / \mathrm{L}$ of different sustrates. 
Microscopic observation indicated that the viable counts and the morphologies of the heterotrophic anaerobic microorganisms were different when bottles were supplemented with different substrates. The viable counts on HA- and acetate-fed batches were similar; in addition, small spheric-shaped cells were predominant in the microcosms. Relatively low cell numbers, large rod-shaped bacteria were observed when bottles were amended with glucose. Also, the batches with the amendment with glucose produced brighter blue dots than those with acetate and HA. This occurrence may account for why glucose-fed batches had relatively better removal efficiencies of chlorinated hydrocarbons, even though they had fewer bacterial cells.

Table 3.The total organic carbon (TOC) of the liquid phases in the substrate-fed batches. The substrates used were acetate, humic acid (HA), glucose, and methanol, respectively. The supplemental concentrations in each substrate-fed batch were 10,20 , and $30 \mathrm{mg} / \mathrm{L}$.

\begin{tabular}{|c|c|c|c|c|c|c|c|c|c|c|c|c|}
\hline \multirow{3}{*}{$\begin{array}{c}\text { Incubation } \\
\text { Times } \\
\text { (days) }\end{array}$} & \multicolumn{12}{|c|}{ TOC in the substrate-fed batches $(\mathrm{mg} / \mathrm{L}$ ) } \\
\hline & \multicolumn{3}{|c|}{$\begin{array}{l}\text { acetate-fed } \\
(\mathrm{mg} / \mathrm{L})\end{array}$} & \multicolumn{3}{|c|}{$\begin{array}{l}\text { HA-fed } \\
(\mathrm{mg} / \mathrm{L})\end{array}$} & \multicolumn{3}{|c|}{$\begin{array}{l}\text { glucose-fed } \\
(\mathrm{mg} / \mathrm{L})\end{array}$} & \multicolumn{3}{|c|}{$\begin{array}{l}\text { methanol-fed } \\
(\mathrm{mg} / \mathrm{L})\end{array}$} \\
\hline & 10 & 20 & 30 & 10 & 20 & 30 & 10 & 20 & 30 & 10 & 20 & 30 \\
\hline 0 & 5.31 & 9.02 & 12.2 & 6.56 & 9.84 & 13.5 & 5.95 & 11.6 & 15.4 & 7.69 & 10.1 & 14.9 \\
\hline 11 & 3.08 & 1.87 & 1.72 & 3.55 & 1.64 & 4.56 & 1.65 & 1.63 & 2.86 & 3.10 & 4.45 & 5.06 \\
\hline 32 & 2.22 & 1.97 & 1.56 & 2.35 & 2.30 & 2.96 & 1.94 & 1.60 & 1.65 & 2.48 & 2.60 & 2.76 \\
\hline 62 & 2.80 & 1.98 & 2.98 & 3.35 & - & 3.38 & 1.40 & 2.83 & 1.93 & 2.54 & 2.97 & 3.22 \\
\hline
\end{tabular}

_ : no data determined.

\section{SUMMARY AND CONCLUSIONS}

This investigation demonstrated that supplementing the substrate is apparently necessary for the dechlorination of highly chlorinated hydrocarbons. Different rates and extents of biotransformation were exhibited when different substrate were fed into the microcosms. Better removal efficiencies were observed to be the greatest for glucose-, methanol-, and acetate-fed batches and the least for HAfed batches, which is consistent with the prediction based on the thermodynamic calculation. The effect of low substrate concentration on the biotransformation of the highly chlorinated hydrocarbons under anaerobic conditions was also evident. Microscopic observations on the samples demonstrated that different morphologies of bacteria were presented. Small sized bacteria with spheric shape were observed when culture bottles were amended with either acetate or HA. Whereas large size with rodshape bacteria were predominant for bottles amended with glucose. 
This investigation highlights the potential significance of the supplemental substrates for groundwater cleanup practices aimed at removing chlorinated hydrocarbons in a contaminated area. The addition of a low concentration of supplemental substrate, which provides high available free energy (reducing power) is conducive to the dechlorination of polychlorinated hydrocarbons. Further work in the area of identification of the metabolic pathways for the chlorinated hydrocarbons and the electron transfer processes would elucidate the role of the auxiliary substrate toward the reductive dechlorination as well as yield maximum results in the field clean-up works.

\section{ACKNOWLEDGEMENTS}

The authors would like to thank the National Science Council, R. O. C. for financial support of this investigation under contract No. NSC 81-041-E002-23. We thank Mr. Ing-Jye Hwang for his excellent help in preparing the manuscript.

\section{LITERATURE CITED}

1. Hisham, M. W., and Grosjean, D., Environ. Sci. Technol., 1991, 25, 1930.

2. Thomas, J. M. and Ward, C. H., Environ. Sci. Technol., 1989, 23, 760.

3. Semprini, L., Hopkins, G. D., McCarty, P. L., and Roberts, P. V., Environ. Sci. Technol., 1992, 26, 2454.

4. DiStefano, T. D., Gossett, J. M., and Zinder, S. H., Appl. Environ. Microbiol., 1991, 57, 2287.

5. Doong, R. A., and Wu, S. C., Wat. Sci. Technol., 1992a, 26, 159-168 .

6. McNab, W. W.Jr. and Narasimhan T. N., Environ. Sci. Technol., 1994, $28,769$.

7. Fathepure, B. Z. and Tiedje, J. M., Environ. Sci. Technol., 1994, 28, 746.

8. Freedman, D. L. and Gossett, J. M., Appl. Environ. Microbiol., 1989, 55, 2144.

9. Criddle, C. S., DeWitt, J. T., and McCarty, P. L. , Appl. Environ. Microbiol.., 1990, 56, 3247.

10.DiStefano, T. D., Gossett, J. M. and Zinder, S. H., Appl. Environ. Microbiol., 1992, 58, 3622.

11.Owen, W. F., Stuckey, J. B. Jr., Healy, L. Y., Young, L. Y. and McCarty, P. L., Wat. Res., 1979, 13,485 .

12.Egli, C., Tschan, T., Scholtz, R., Cook, A. M. and Leisinger, T., Appl. Environ. Microbiol., 1988, 54, 2819.

13.Light, T. S., Analy. Chem., 1972, 44, 1038.

14.Parsons, F., Barrio-Lage, G. B. and Rice R., Environ. Toxicol. Chem. 1985, 4, 379.

15.Coleman, A. W., Limnol. Oceanogr., 1980, 25, 948.

16.Doong, R. A. and Wu, S. C., Chemosphere, 1992, 24, 1063

17.Kriegman-King, M. R. and Reinhard, M. Environ. Sci. Technol., 1994, 28, 692.

18.Assaf-Anid, N., Hayes, K. F., and Vogel, T. M., Environ. Sci. Technol., 1994, $28,246$.

19.Bouwer, E. J. and McCarty, P. L., Appl. Environ. Microbiol., 1983, 45, 1295.

20.Nies, L. and Vogel, T. M., Appl. Environ. Microbiol., 1990, 56, 2612.

21.Gibson, S. A. and Sewell G. W., Appl. Environ. Microbiol., 1992, 58, 1392. 
22.Fathepure, B. Z., and Vogel, T. M., Appl. Environ. Microbiol., 1991, 57, 3418.

23.Kastner, M., Appl. Environ. Microbiol., 1991, 57, 2039. 